\title{
FAKTOR YANG MEMENGARUHI STATUS GIZI BALITA DI PUSKESMAS MUTIARA
}

\author{
JULIATI \\ Akademi Kebidanan Darul Husada Sigli \\ e-mail: juliatiinfo@gmail.com
}

\begin{abstract}
ABSTRAK
Berdasarkan data Dinas Kesehatan Aceh mengidentifasi(mencatat) atau meperkirakan ada sekitar 3.125 kasus bayi atau anak balita di bawah umur lima tahun yang mengalami masalah gizi di wilayah Aceh atau seluruh Aceh. Jumlah yang telah di dapatkan itu di sesuaikan pada data-data yang dimiliki oleh Dinkes Aceh. Sementara itu Dinas Kesehatan Pidie mencatat ada tiga kasus gizi buruk yang terbaru yang ditemui dari Januari hingga Maret 2019, dimana satu di Kembang Tanjung dan dua di Kecamatan Tangse. Disebutkan, pada ketiga kasus anak balita ini memiliki gizi buruk dan sehingga ini juga dalam pengawasan pihak dinas. Status gizi adalah keadaan keseimbangan antara asupan dan kebutuhan zat gizi. Status gizi baik bila jumlah asupan zat gizi sesuai dengan yang dibutuhkan. Status gizi tidak seimbang dapat diprestasikan dalam bentuk gizi kurang dari yang dibutuhkan. Sedangkan status gizi lebih bila asupan zat gizi melebihi dari yang dibutuhkan.Tujuan Penelitian ini adalah untuk Mengidentifikasi faktor yang memengaruhi status gizi balita di wilayah kerja Puskesmas Mutiara Kabupaten Pidie Tahun 2019. Penelitian ini Kuantitatif dengan pendekatan Quasi Eksperiment. Penelitian ini telah dilakukan pada bulan Maret s/d Juli Tahun 2019. Populasi dalam penelitian ini seluruh ibu yang mempunyai balita di Puskesmas Mutiara. Syamtalira Aron dengan jumlah sampel sebanyak 37 orang. Alat pengumpulan data dengan membagikan kuesioner. Metode pengolahan data dengan cara editing,coding, transfering, dan tabulating. Hasil penelitian didapat ibu yang pengetahuan tinggi sebanyak 5 $(13,5 \%)$ dan ibu yang pengetahuan sedang sebanyak $14(53,5 \%)$ dan ibu yang pengatahuan kurang sebanyak $18(48,7 \%)$. Hasil uji pairet $\mathrm{T}$-Test didapat $\mathrm{P}$ Value $=0,763>\mathrm{a}(0,05)$, maka kesimpulannya ada bahwa pada aipha $5 \%(0,05)$ ho diterima, artinya tidak ada hubungan yang signifikan antara status gizi balita dengan pengetahuan atau pekerjaan ibu.
\end{abstract}

Kata Kunci : Faktor Yang Memengaruhi Status Gizi Balita Budaya Ibu, Jumlah anak, dan pendidikan ibu

\section{PENDAHULUAN}

Fase terpenting dalam pertumbuhan dan perkembangan adalah masa bayi dan balita karena pada masa itulah saat paling penting bagi orang tua dalam membangun fondasi pertumbuhan dan perkembangan buah hati. Proses pertumbuhan dan perkembangan pada masa bayi dan balita merupakan proses yang teramat penting dalam menentukan masa depan anak baik secara fisik, mental maupun perilaku (Maryunani, 2010).

Salah satu upaya untuk mengetahui adanya penyimpangan pada perkembangan anak adalah dengan deteksi dini, sehingga upaya pencegahan, stimulasi, penyembuhan daan pemulihan dapat diberikan secara benar sesuai dengan indikasinya. Deteksi untuk tumbuh kembang ini merupakan suatu upaya yang perlu didukung, karena merupakan salah satu cara untuk mempersiapkan generasi mendatang yang berkualitas (Yuniarti, 2015).

Keadaan gizi merupakan gambaran apa yang dikonsumsi oleh seseorang dalam jangka waktu yang lama. Karena itu, ketersediaan zat gizi di dalam tubuh seseorang termasuk bayi dan balita menentukan keadaan gizi bayi dan balita apakah kurang, optimum atau lebih. Makanan yang diberikan pada bayi dan balita akan digunakan untuk pertumbuhan badan, karena itu status gizi dan pertumbuhan dapat dipakai sebagai ukuran untuk memantau kecukupan gizi bayi dan balita, dimana seluruh pertumbuhan dan kesehatan balita erat kaitannya dengan masukkan makanan yang 
memadai. Pertumbuhan dan perkembangan yang optimal pada balita memerlukan makanan yang sesuai dengan balitayang sedang tumbuh (Maryunani, 2010).

Kurangnya asupan makanan balita yang bergizi dan kemampuan orang tua dalam memantau pertumbuhan dan perkembangan balitanya adalah faktor yang paling utama mempengaruhi status gizi balita. Sedangkan faktor yang mempengaruhi status gizi balita adalah ketersediaan pangan di tingkat keluarga, pola asuh keluarga, kesehatan lingkungan, budaya keluarga, dan sosial ekonomi. Konsumsi makanan berpengaruh terhadap status gizi seseorang sehingga memungkinkan terjadinya pertumbuhan fisik, perkembangan otak, kemampuan kerja untuk mencapai tingkat kesehatan optimal (Kemenkes RI, 2011).

Seorang ibu yang memiliki pengetahuan dan sikap gizi yang kurang akan sangat berpengaruh terhadap status gizi balitanya dan akan sukar untuk memilih makanan yang bergizi untuk anaknya dan keluarganya. Gizi yang baik adalah gizi yang seimbang, artinya asupan zat gizi harus sesuai dengan kebutuhan tubuh. Gizi kurang pada anak di usia balita membawa dampak pertumbuhan otak dan tingkat kecerdasan terganggu, hal ini disebabkan karena kurangnya mengkonsumsi protein dan kurangnya energi yang diperoleh dari makanan dan pengetahuan juga sikap ibu sangat penting untuk mencegah terjadinya gizi buruk.

Kementerian Kesehatan akan memfokuskan peningkatan gizi masyarakat dan telah tercamtum pada rencana strategis (Renstra) Kemenkes 2020-2024. Berdasarkan hasil riset kesehatan dasar, kondisi gizi balita telah menunjukkan perbaikan .pada masalah stunting terjadi penurunan prevalensi pada anak balita dari 37,21\% di tahun 2014 menjadi 30,79\% (Kemenkes RI, 2011).

Pada Maret 2018, yang melibatkan 320.000 rumah tangga (RT) yang memiliki balita untuk melihat status gizi balita. Hasil dari SSBGI Tahun 2018, telah terjadi penurunan prevalensi stunting dari 30,8\% tahun 2018 menjadi 27,67\% (Kemenkes RI, 2019). Dinas Kesehatan Aceh mengidentifasi sekitar 3.125 kasus bayi atau anak balita yang mengalami masalah gizi di wilayah Aceh. Jumlah yang telah di dapatkan disesuaikan pada data Dinkes Aceh pada Juni 2019?

Sementara itu Dinas Kesehatan Pidie mencatat ada tiga kasus gizi buruk yang terbaru yang ditemui dari Januari hingga Maret 2019, dimana satu di Kembang Tanjung dan dua di Kecamatan Tangse. Disebutkan, pada ketiga kasus anak balita ini memiliki gizi buruk dan sehingga ini juga dalam pengawasan pihak dinas?

Berdasarkan hasil studi pendahuluan dan uraian di atas, maka penelitian tertarik untuk melakukan penelitian tentang "Faktor yang memengaruhi status gizi balita di Puskesmas Mutiara Kabupaten Pidie"

\section{METODE PENELITIAN}

Jenis penelitian yang digunakan adalah penelitian analitik dengan desain penelitian Cross Sectional, penelitian cross-sectional adalah suatu penelitian untuk mempelajari dinamika korelasi antara faktor-faktor risiko dengan efek, dengan cara pendekatan, observasional, atau pengumpulan data yang merupakan rancangan penelitian dengan melakukan pengukuran atau pengamatan pada waktu penelitian sedang berlangsung. Untuk melengkapi data primer peneliti memperoleh data dari kader dan bidan desa, selanjutnya peneliti mendatangi sampel, dan melakukan pengumpulan data. Sampel dalam penelitian ini berjumlah 37 balita yang terdata di wilayah Kerja Puskesmas Mutiara Kabupaten Pidie. Analisis yang telah dianalisis dilakukan dengan distribusi frekuensi dari tiap-tiap variabel independen (Faktor yang memengaruhi) dan variabel dependen ( Status Gizi).

\section{HASIL DAN PEMBAHASAN}

\section{Hasil}

Penelitian ini dilakukan di Wilayah Kerja Puskesmas Mutiara Timur Kabupaten Pidie. Dari data yang di kumpulkan terdapat 37 orang sampel. Penelitian ini mulai dilakukan pada bulan April 
s/d Juni dan data di peroleh melalui kuesioner. Dari hasil penelitian yang berjudul Faktor Yang Memengaruhi Status Gizi Balita Di Wilayah Kerja Puskesmas Mutiara Kabupaten Pidie tahun 2019 di dapatkan hasil sebagai berikut :

Tabel 1. Karakteristik Responden Di Wilayah Kerja Puskesmas Mutiara Kabupaten Pidie Berdasarkan Budaya

\begin{tabular}{cccc}
\hline NO & Budaya & Frekuensi (f) & Persentase (\%) \\
\hline 1. & Beresiko & 14 & 37,8 \\
2. & Tidak Beresiko & 23 & 62,1 \\
& Jumlah & 37 & 100 \\
\hline
\end{tabular}

Sumber data :Data Primer (diolah tahun 2019)

Berdasarkan Tabel 1 menunjukkan bahwa dari 37 responden, mayoritas berdasarkan budaya antara beresiko yaitu 14 ( 37,8), dan tidak beresiko $23(62,1)$.

Tabel 2. Karakteristik Responden Di Wilayah Kerja Puskesmas Mutiara Kabupaten Pidie Berdasarkan Pekerjaan

\begin{tabular}{cccc}
\hline No & Pekerjaan & Frekuensi (f) & Persentase (\%) \\
\hline 1. & IRT & 20 & 54,0 \\
2. & Pedagang & 11 & 29,7 \\
3. & Bidan & 1 & 2,7 \\
4. & Perawat & 2 & 5,4 \\
5. & Guru & 3 & 8,1 \\
& Jumlah & 37 & 100 \\
\hline
\end{tabular}

Sumber dat : Data Primer ( diolah tahun 2019)

Berdasarkan Tabel 2 menunjukkan bahwa dari 37 responden, mayoritas responden berkerja sebagai IRT yaitu 20 responden $(54,0 \%)$.

Tabel 3. Karakteristik Responden Di Wilayah Kerja Puskesmas Mutiara Kabupaten Pidie Berdasarkan Pengetahuan Gizi Ibu

\begin{tabular}{cccc}
\hline No & Pengetahua gizi ibu & Frekuensi (f ) & Persentase (\%) \\
\hline 1. & Tinggi & 5 & 13,5 \\
2. & Sedang & 14 & 37,8 \\
3 & Rendah & 18 & 48,7 \\
& Jumlah & 37 & 100 \\
\hline
\end{tabular}

Sumber data: Data Primer ( diolah tahun 2019)

Berdasarka tabel 3 menunjukan bahwa dari 37 responden, mayoritas responden pengetahuan tinggi gizi ibu menunjukkan bahwa sebanyak 5 responden $(13,5 \%)$ yang pengetahuan sedang dan sebanyak 14 responden ( 53,5\%) yang penegtahuan kurang dan yg rendah 18 responden (48,7\%).

Tabel 4. Karakteristik Responden Di Wilayah Kerja Puskesmas Mutiara Kabupaten Pidie Berdasarkan Jumlah Anak

\begin{tabular}{cccc}
\hline No & Jumlah Anak & Frekuensi (f) & Persentase (\%) \\
\hline 1. & $1-2$ & 26 & 70,2 \\
2. & $>2$ & 11 & 29,7 \\
& Jumlah & 37 & 100 \\
\hline
\end{tabular}

Sumber data : Data Primer ( diolah tahun 2019) 
Berdasarkan tabel 4 menunjukkan bahwa dari 37 responden mayoritas responden jumlah anak menunjukkan bahwa sebanyak 26 responden ( 70,2\%) yang jumlah anaknya 1-2 dan sebanyak 11 responden ( $29,7 \%$ ) yang jumlah anaknya $>2$ orang.

Tabel 5. Karakteristik Responden Di Wilayah Kerja Puskesmas Mutiara Kabupaten Pidie Berdasarkan Pendapatan Keluarga

\begin{tabular}{cccc}
\hline No & Pendapatan Keluarga & Frekuensi (f) & Persentase (\%) \\
\hline 1. & Kurang & 20 & 54,0 \\
2. & Baik & 17 & 45,9 \\
& Jumlah & 37 & 100 \\
\hline
\end{tabular}

Sumber data : Data Primer (diolah tahun 2019)

Berdasarkan tabel 5 menunjukkan bahwa dari 37 responden, mayoritas responden pendapatan keluarga menunjukkan bahwa sebanyak 20 responden $(54,0 \%)$ yang pendapatan keluarganya kurang dan sebanyak 17 responden $(45,9 \%)$ yang pendapatan keluarganya baik.

Tabel 6. Karakteristik Responden Di Wilayah Kerja Puskesmas Mutiara Kabupaten Pidie Berdasarkan Jumlah Anggota Keluarga

\begin{tabular}{cccc}
\hline No & Jumlah Anggota Keluarga & Frekuensi (f) & Presentase (\%) \\
\hline 1. & Kecil & 25 & 67,5 \\
2. & Besar & 12 & 32,4 \\
& Jumlah & 37 & 100 \\
\hline
\end{tabular}

Sumber data : Data Primer ( diolah tahun 2019)

Berdasarkan tabel 6 menunjukka bahwa dari 37 responden, mayoritas responden jumlah anggota keluarga menunjukkan bahwa sebanyak 25 responden $(67,5 \%)$ yang jumlah anggota keluarganya kecil dan sebanyak 12 responden $(32,4 \%)$ yang jumlah anggota keluarganya besar.

Tabel 7. Karakteristik Responden Di Wilayah Kerja Puskesmas Mutiara Kabupaten Pidie Berdasarkan Pendidikan Terakhir Ibu

\begin{tabular}{cccc}
\hline No & Pendidikan Terakhir Ibu & Frekuensi (f) & Persentase (\%) \\
\hline 1. & Rendah & 9 & 24,3 \\
2. & Menengah & 22 & 59,4 \\
3. & Tinggi & 6 & 16,2 \\
& Jumlah & 37 & 100 \\
\hline
\end{tabular}

Sumber data: Data Primer ( diolah tahun 2019)

Berdasarkan tabel 7 menunjukkan bahwa dari 37 responden, mayoritas responden berpendidika rendah yaitu 9 responden $(24,3 \%)$, berpendidikan menengah yaitu 22 responden $(59,4 \%)$, dan berpendidika tinggi 6 responden $(16,2 \%)$.

1. Analisa univariat

a. Pengetahuan

Tabel 8. Distribusikan Frekuensi Penegetahuan Tantang Faktor Yang Memengaruhi Status Gizi Balita Di Wilayah Kerja Puskesmas Mutiara Kabupaten Pidie Tahun 2020

\begin{tabular}{cccc}
\hline No & Pengetahuan & Frekuensi & Presentase (\%) \\
\hline 1. & Baik & 33 & 89,1 \\
2. & Kurang & 4 & 10,8 \\
\hline
\end{tabular}




\begin{tabular}{rrr}
\hline Jumlah & 37 & 100 \\
\hline
\end{tabular}

Sumber data : Data Primer ( diolah tahun 2019)

Berdasarkan tabel 8 menunjukkan bahwa dari 37 responden, mayoritas ibu berpengetahuan baik sebanyak 33 responden ( 89,1 ) dibandingkan dengan yang kurang (10,8\%)).

b. Status Gizi Balita

Tabel 9 . Distribusikan Frekuensi Status Gizi Balita Di Wilayah Kerja Puskesmas Mutiara Kabupaten Pidie Tahun 2020

\begin{tabular}{cccc}
\hline No & Status Gizi Balita & Frekuensi & Persentensen (\%) \\
\hline 1. & Baik & 1 & 2,7 \\
2. & Kurang & 36 & 97,2 \\
& Jumlah & 37 & 100 \\
\hline
\end{tabular}

Sumber data : Data Primer (diolah tahun 2019)

Berdasarkan tabel 9 menunjukkan bahwa dari 37 responden, mayoritas ibu tentang status gizi balita yang kurang $(97,2 \%)$ dibandingkan dengan status gizi yang baik $(2,7)$.

2. Analisa Bivariat

a. Pengetahuan ibu tentang faktor yang memengaruhi status gizi balita

\section{Tabel 10. Distribusikan Frekuensi Faktor Yang Mempengaruhi Status Gizi Balita Di Wilayah Kerja Puskesmas Mutiara Kabupaten Pidie Tahun 2020}

\begin{tabular}{cccccccccc}
\hline \multirow{2}{*}{ No } & & \multicolumn{4}{c}{ Status gizi balita } & \multicolumn{4}{c}{ P } \\
\cline { 3 - 6 } & & \multicolumn{2}{c}{ Baik } & \multicolumn{2}{c}{ Kurang } & F & Value & a \\
& & F & $\%$ & F & $\%$ & & & \\
1 & Kurang & 0 & $0,0 \%$ & 3 & $100 \%$ & 3 & $100 \%$ & & \\
2 & Baik & 1 & $2,9 \%$ & 33 & $97,1 \%$ & 34 & $100 \%$ & 0,763 & 0,05 \\
& Jumlah & 1 & $2,7 \%$ & 36 & $97,3 \%$ & 37 & $100 \%$ & & \\
\hline
\end{tabular}

Sumber data : Data Primer ( diolah tahun 2019)

Berdasarkan tabel 10 hasil analisa Faktor yang memengaruhi status gizi balita di peroleh bahwa dari 37 responden. Diperoleh bahwa ibu yang benar dalam pengetahuan gizi lebih banyak dilakukan oleh ibu yang pengetahuannya kurang (100\%) di bandingkan dengan pengatahuan Baik $(97,1 \%)$. Hasil analisa continuity correction di peroleh $\mathrm{p}$ value $=0,763$ maka dapat disimpulkan bahwa pada aipha 5\% $(0,05)$ ho diterima, artinya tidak ada hunbungan yang signifikan antara status gizi balita dengan pengetahuan atau pekerjaan ibu.

\section{Pembahasan}

Penelitian ini dilakukan dengan cara pengumpulan data melalui penguku- ran berat badan dan kuisioner. Pengumpulan data primer dengan menggunakan kuisioner, sedangkan pengumpulan data sekunder diperoleh dari Puskesmas Mutiara. Dalam rancangan penelitian ini peneliti melakukan observasi tiap keluarga dalam hal ini ibu dan balitanya yang termasuk dalam kriteria inklusi. Setelah itu peneliti mengukur berat badan dan kemudian membagikan kuesioner pada tiap ibu. Sebelum kuesioner diisi, peneliti menginformasikan tentang tujuan penelitian dan sifat keikutsertaan responden dalam penelitian, cara pengi sian kuesioner, dan sebelum responden mengisi seluruh pertanyaan yang terse- dia dalam kuesioner penelitian, responden terlebih dahulu menandatangani lembar persetujuan penelitian (informed concent).

Setelah data hasil penelitian terkumpul, kemudian dilakukan penyuntingan data, pengkodean data, dan entri data ke dalam master tabel. Data kemudian diolah menggunakan 
program SPSS. Dari hasil pengolahan disajikan kedalam tabel frekuensi dan distribusi serta penjelasan dalam bentuk narasi.

1. Faktor yang memengaruhi status gizi balita di wilayah kerja Puskesmas Mutiara Kabupaten Pidie Tahun 2019.

Berdasarkan tabel 10 hasil analisa Faktor yang memengaruhi status gizi balita di peroleh bahwa dari 37 responden. Diperoleh bahwa ibu yang benar dalam pengetahuan gizi lebih banyak dilakukan oleh ibu yang pengetahuannya kurang (100\%) di bandingkan dengan pengatahuan Baik $(97,1 \%)$. Hasil analisa continuity correction di peroleh $\mathrm{p}$ value $=0,763$ maka dapat disimpulkan bahwa pada aipha $5 \%(0,05)$ ho diterima, artinya tidak ada hunbungan yang signifikan antara status gizi balita dengan pengetahuan atau pekerjaan ibu Di Wilayah Kerja Puskesmas Mutiara Kabupaten Pidie Tahun 2019.

Status gizi adalah keadaan kesehatan sebagai hasil masukan zat gizi (Maryunani, 2010). Konsumsi makanan yang bergizi dapat menentukan tercapainya tingkat kesehatan. Seseorang dapat mengetahui bagaimana konsumsi makanan yang bergizi baik dengan cara mengetahuinya. Apabila seseorang kurang mengetahui tentang gizi dan konsumsinya maka akan mempengaruhi kondisi gizinya karena seseorang tersebut akan mengkonsumsi makanan sesuka hatinya tanpa memperhitungkan asupan gizi yangbaik. Jadi status gizi balita dikatakan baik yakni apabila terdapat keseimbangan antara zat gizi yang masuk dalam tubuh dan yang diperlukan dalam kegiatan sehari-hari.

Bedasarkan hasil penelitian, ada beberapa aspek yang paling berpengaruh terhadap efektivitas status gizi balita sebelum dan setelah dilakukan pemberian edukasi dengan perbendaan yang sangat signifikasi. Hal ini berhubungan dengan faktor-faktor seperti tingkat pengalaman ibu, teknologi dan informasi yang mudah untuk diakses dan program-program yang dilakukan oleh fasilitas kesehatan, sehingga membuat masyarakat paham mengenai status gizi balita atau pemberian makanan terhadap balita.

Hasil penelitian ini sejalan dengan penelitian yang dilakukan oleh Susanti et al.,(2014) yang menyatakan adanya hubungan antara pengetahuan ibu tentang gizi anak dengan status gizi anak usia 1-3 tahun di wilayah kerja puskesmas rejosari kelurahan sail kecamatan tenayan raya kota pekanbaru. Penelitian ini juga dilakukan Susilowati \& Himawati (2017) tentang hubungan tingkat pengetahuan ibu dengan status gizi balita di wilayah kerja puskesmas Gajah 1 Demak menunjukkan bahwa ada hubungan yang signifikan antara tingkat pengetahuan ibu tentang gizi balita dengan status gizi balita.

Pada penelitian ini, beberapa responden masih belum mencapai efektivitas sebelum dilakukan pemberian edukasi tentang gizi untuk balita dengan skor penilaian efektif $>7$. Meskipun demikian, sebagian besar responden dengan skor penilaian efektif $\geq 7$ yang artinya efektif, namun ada beberapa indikator penting dari penilaian yang masih belum tercapai. Indikator tersebut diantaranya adalah masih kuat tentang pemahaman budaya, ibu suka memberikan makanan di luar ke pada balita, dan makanan yang cepet saji.

Tingkat pengetahuan ibu tentang gizi balita sangat mempengaruhi keadaan gizi balita tersebut karena ibu adalah seorang yang paling besar keterikatannya terhadap anak. Kebersamaan ibu dengan anaknya lebih besar dibandingkan dengan anggota keluarga yang lain sehingga lebih mengerti segala kebutuhan yang dibutuhkan anak. Pengetahuan yang dimiliki ibu menjadi kunci utama kebutuhan gizi balita terpenuhi. Pengetahuan yang didasari dengan pemahaman yang baik dapat menumbuhkan perilaku baru yang baik pula. Pengetahuan ibu tentang kebutuhan gizi yang dipahami dengan baik akan diiringi dengan perilaku pemberian makanan bergizi bagi balita. Pengetahuan bisa didapat dari informasi berbagai media seperti TV, radio atau surat kabar seperti halnya dalam penelitian ini. ibu mendapatkan informasi tentang kebutuhan gizi balita dari penyuluhan yang diberikan puskesmas setiap pelaksanaan program posyandu. Informasi ini 
meningkatkan pengetahuan yang diiringi dengan perilaku baru dalam pemberian makanan bergizi bagi balita sehingga status gizi pun menjadi baik (Susilowati \& Himawati, 2017).

\section{KESIMPULAN}

Berdasarkan dari hasil penelitian dan pembahasan faktor yang memengaruhi status gizi balita di wilayah puskesmas mutiara kabupaten pidie tahun 2019, dapat di ambil kesimpulan bahwa :

1. Pengetahuan di wilayah kerja puskesmas mutiara kabupaten pidie mayoritas aktif.

2. Pemberian makan pada balita di wilayah kerja puskesmas mutiara kabupaten pidie mayoritas salah.

3. Tidak ada hubungan yang signifikasi anatar status gizi balita dengan pengetahuan atau pekerjaan ibu.

\section{DAFTAR PUSTAKA}

Achmad Djaeni Sediaoetama. (2017). Ilmu Gizi untuk mahasiswa dan profesi jilid I. Jakarta : Dian rakyat

Achmad Djaeni Sediaoetama. (2017). Ilmu Gizi untuk mahasiswa dan profesi .edisi kelima . Jakarta : Dian rakyat

Almatsier, S. (2016). Prinsip Dasar Ilmu Gizi. Jakarta: PT Gramedia Pustaka Utama.

Arisman, MB. (2017). Gizi Daur Hidup. Jakarta: Penerbit Buku Kedokteran EGC.

Beck. (2017). Status Gizi. [Online] http://www.creasoft.com, diakses tanggal, 25 april 2017.

Candra, R N. (2016). Hubungan Pola Konsumsi Makanan Jajanan Dengan Status Kesehatan

Anak Usia Sekolah Di SDN Ketintang I Surabaya. Ejournal Boga. 2.

Depdikbud. (2015). Kamus Besar Bahasa Indonesia. Jakarta: Balai Pustaka

Depkes RI. (2015). Pedoman Praktis Terapi Gizi Medis. Jakarta : Depkes RI

Kementerian Kesehatan RI. Pedoman penyediaan makanan tambahan anak sekolah. Keputusan menteri dalam negeri no.18 Tahun 2011.

Kemenkes RI. (2019). Pemantauan status gizi dilakukan seluruh kabupaten/kota di Indonesia. http://www.kemenkesRI.go.id. (diakses tanggal 25 April 2019).

Maryunani, Anik. (2010). Ilmu kesehatan anak dalam kebidanan. Jakarta; Tunas Info Media

Notoadmodjo S. (2002). Metodelogi penelitian kesehatan. Jakarta: PT. Rineka Cipta.

Nurul. (2016). Jumlah Anggota Keluarga. Grahan Ilmu.

Sulistyoningsih H. (2016). Umur ibu. Jakarta : Trans Info Media.

Sri. (2016). Pengetahuan Gizi Ibu. Jakarta.

Suhendri. (2017). Pekerjaan Ibu. Grahan Ilmu.

Susanti, R., Indriati, G., \& Utomo, W. (2014). Hubungan Pengetahuan Ibu tentang Gizi dengan Status Gizi Anak Usia 1-3 Tahun. Jom PSIK, 1(2), 1-7

Susilowati, E., \& Himawati, A. (2017). Hubungan Tingkat Pengetahuan Ibu tentang Gizi Balita dengan Status Gizi Balita di Wilayah Kerja Puskesmas Gajah 1 Demak. Jurnal Kebidanan, 6(13), 21-25

Sukmawandari. (2016). Pendapatan Keluarga. Jakarta

Yuniarti, Sri. (2010). Asuhan tumbuh kembang neonatus, bayi, balita dan anak pra sekolah. Bandung: Revika Aditama. 